UDC 628.9:662.92; 538.953-405

\author{
Bolegenova S.A., Askarova A.S., Bekmukhamet A., Bolegenova S., \\ Maximov V., *'Ospanova Sh., Manabayeva R., Utelov S. \\ Al-Farabi Kazakh National University, IETP, al-Farabi 71, 050040 Almaty, Kazakhstan \\ *e-mail: shinar_ospanova87@mail.ru
}

\title{
3D modeling high temperature flows in the combustion chambers of the power plants
}

\begin{abstract}
In this paper the results obtained by the numerical method of modelling of Ekibastuz coal burning in BKZ-420 combustion chamber of Kazakhstan's coal-fired Power Plant are presented. They are devoted to the numerical simulation of combustion processes in the furnace boiler BKZ-420. Boiler's steam generating capacity $420 \mathrm{~T} / \mathrm{h}$. Boiler has six vertical pulverized coal burners arranged in two levels with three burners on the front wall of the boiler. High ash, low-grade coal from Ekibastuz burned in the furnace. Its ash content is $39 \%$, volatile $-24 \%$, humidity $-5 \%$, highest calorific value is $16750 \mathrm{~kJ} / \mathrm{kg}$. In this research the main harmful gases distribution characteristics of the concentration of carbon oxides $\left(\mathrm{CO}\right.$ and $\left.\mathrm{CO}_{2}\right)$, nitrogen dioxide $\left(\mathrm{NO}_{2}\right)$, and oxygen $\mathrm{O}_{2}$ are shown. Key words: fuel, turbulent flow, numerical method, boiler, burner, high-energy fuel.
\end{abstract}

\section{Introduction}

It is now one of the fastest growing areas in sources in more efficient and economical way. The efficient combustion of solid fuel in combustion chambers and the efficient heat transfer to water and steam in steam generators are essential for the economical operation of power plants. Heat transfer problems pertaining to the combustion in industrial furances are great importance to the engineering designer of boilers and steam generators in most industrial flame applications, the achievement of high heat transfer rates is a main target and desirable. According to the IEA coal is estimated to remain the second largest source of energy also in the years to come [1-3]. Over the longer term, coal is even projected to again become the number one primary source of energy. Figure 1 is showing the past and future shares of primary energy amongst different sources. This scenario assumes the increase in coal consumption, based on the proven fossil fuel reserves and the future development of new technologies, the increase in utilisation of renewables, especially of biomass, and the decline of oil and gas consumption.

At the present work by means of 3D - Finite Volume (Fig-2) simulation tool FLOREAN developed at the institute for Heat and Fuel technology TU Braunschweig heat and mass transfer processes in furnaces with swirl burners in box-firing system are considered [4-5].
On the front wall of the BKZ-420 boiler furnace are six dual-flow pulverized coal burner (Fig. 2) on two levels include three stages. The extreme burner turned to the center of furnace by 8 degrees. We can see on the Figure 3 and in the opposite side wall of the burner area of second layer has a hole for feeding secondary air to the center turned 45 degrees and whose dimensions $14 \times 60 \mathrm{sm}$. Productivity of one burner $12 \mathrm{t} / \mathrm{h}$ of Ekibastuz coal. In carrying out computational experiments at the initial stage you need to build the geometry of the object, as well as get it finite difference grid.

Industrial implementation of any new technology is not possible without preliminary analysis of advantages and disadvantages suggested method. The rapid development in computer sciences gives the advance to computational techniques to be used for simulation of complex combustion processes in industrial furnaces. Products of combustion contain different harmful substances and the emission of these components grows into a great problem. Industrial development causes an increase in hydro carbonaceous fuels' consumption. These fuels contain harmful and poisonous components such as carbonic oxide (CO), nitric oxide (NO), sulphur dioxide, acid sulphate, lead combinations and different hydrocarbons, etc.

To decrease emissions of harmful substances various methods are applied, including special fire regimes (organization of combustion process),

Printed in Kazakhstan 
which suppresses the formation of harmful substances in flame and two-stage burning, when the burners work with low air surplus. In this way numerical experiments became one of the most effective and suitable means for detail analysis and in-depth study of physical and chemical phenomena.

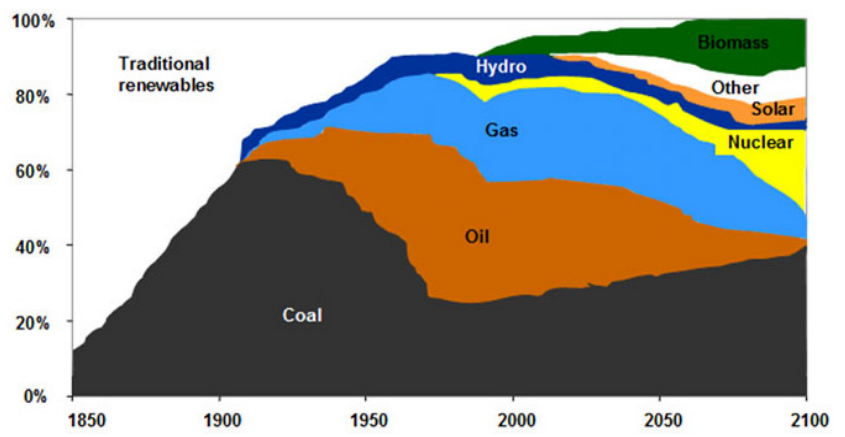

Figure 1 - Historic and future world primary energy mix (scenario 2100) Source: World Coal Institute 2014

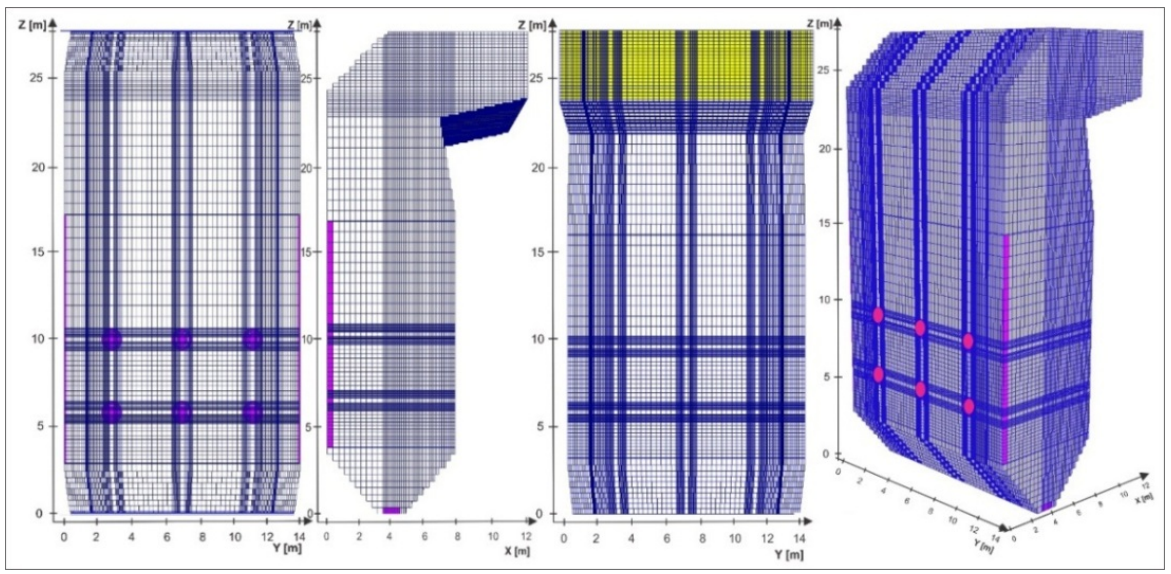

Figure 2 - General view of the BKZ-420 combustion chamber of the Almaty TPP-2 on the control volumes

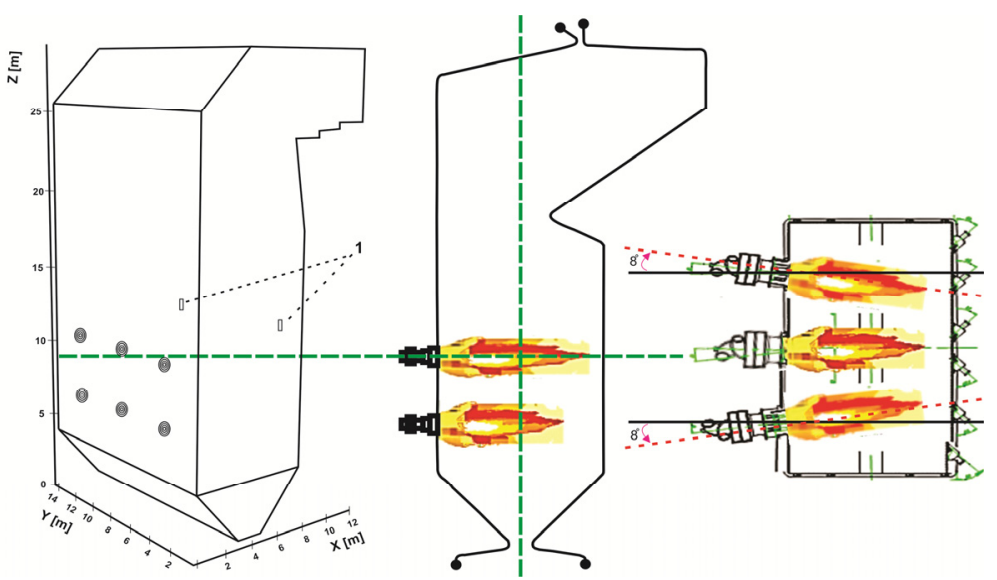

Figure 3 - General view of the BKZ-420 combustion chamber 


\section{Mathematical model}

Among the methods of modeling the combustion of pulverized fuel most widely used method based on the Euler, an approach to describe the motion and heat transfer of the gas phase. This method uses the spatial balance equations for mass, momentum, the concentrations of gaseous components and energies for the gas mixture. To describe the motion of single particles and heat mass transfer of fuel along their trajectories used Lagrange approach. Turbulent flow structure is described by a two-parameter of k- $\varepsilon$ model of turbulence, where $\mathrm{k}$ - the kinetic energy of turbulence, $\varepsilon$ - turbulent energy of dissipation. The mathematical description of physical and chemical processes based on the solution of balance equations. In general, these equations contain four terms describing:

- change in the value of time;

- convective transfer;

- diffusive transfer;

- source or sink.

In general, for numerical solution the whole computational domain is divided into discrete difference grid point, or volume, continuous field variables is replaced by discrete values at the nodes of the grid, and derivatives in the differential equations are replaced by their approximate expressions in terms of the difference of function values at grid points. In the present study for the problem is solved using the method of control volume. The system of algebraic equations for the differential equation of control volume for each balanced value is as follows:

$$
a_{P} \phi_{P}=\sum_{n} a_{n} \phi_{n}+S_{\phi}
$$

Coefficients are determining the contribution of convective and diffusive flow in all directions at each point of control volume. As a result of approximation of equation were obtained algebraic equation for each control volume and for each unknown variable $\phi_{n}$. For each cell in the computational domain used physical laws of conservation and differential equations describing these laws (transfer equation), integrated over the volume of each cell. FLOREAN is based on the numerical solution of the Reynolds averaged balance equations for mass, species, energy and momentum. It predicts gas flows, species concentrations, temperature fields due to combustion, radiation and convective heat transfer and the pollutant formation and destruction in furnace chambers. The mean flow equations are investigated by the $k-\varepsilon$ turbulence model.

The changes of the concentrations of flue gas components and the fuel due to the combustion are taken into account in the source sink terms by appropriate sub models. In addition, in the source sink term the heat balance takes into account the energy release due to the combustion reactions and the significant heat transfer due to radiation using a six flux radiation model. Equation for conservation of thermal energy is written in terms of the enthalpy $h$. Radiation heat transfer is determined by 6 flux radiation models by Lockwood, etc. [6-7].

Pulverized coal flames are turbulent reacting two-phase flows. Particle presence is approximated as continuum and the mean particle velocity is assumed to be approximately equal to the gas phase velocity. In the standard $k-\varepsilon$ model written basic transport equation of turbulent kinetic energy $k$ :

$$
\frac{\partial(\bar{\rho} k)}{\partial t}=-\frac{\partial\left(\bar{\rho} \bar{u}_{j} k\right)}{\partial x_{j}}+\frac{\partial}{\partial x_{j}}\left[\frac{\mu_{e f f}}{\sigma_{k}} \frac{\partial k}{\partial x_{j}}\right]+P-\bar{\rho} \cdot \varepsilon
$$

where, $\mathrm{P}$ - production of turbulent kinetic energy, which is defined by the following equation:

$$
P=\left[\mu_{t u r b} \cdot\left(\frac{\partial \bar{u}_{i}}{\partial x_{j}}+\frac{\partial \overline{u_{j}}}{\partial x_{i}}\right)-\frac{2}{3} \cdot \rho \cdot k \cdot \delta_{i j}\right] \cdot \frac{\partial \overline{u_{i}}}{\partial x_{j}}
$$

The equation for the turbulent kinetic energy dissipation $\varepsilon$ was written as:

$$
\frac{\partial(\bar{\rho} \varepsilon)}{\partial t}=-\frac{\partial\left(\bar{\rho} \bar{u}_{j} \varepsilon\right)}{\partial x_{j}}+\frac{\partial}{\partial x_{j}}\left[\frac{\mu_{e f f}}{\sigma_{\varepsilon}} \frac{\partial \varepsilon}{\partial x_{j}}\right]+C_{\varepsilon, 1} \cdot \frac{\varepsilon}{k} \cdot P-C_{\varepsilon, 2} \cdot \frac{\varepsilon^{2}}{k} \cdot \bar{\rho}
$$


The turbulent viscosity is determined by the equation of Prandtl - Kolmogorov:

$$
\mu_{t}=C_{\mu} \cdot \rho \cdot \frac{k^{2}}{\varepsilon}
$$

where these are empirical constants [8]:

$$
\begin{gathered}
C_{\mu}=0.09 ; \quad \sigma_{k}=1.00 ; \quad \sigma_{\varepsilon}=1.30 ; \\
C_{1 \varepsilon}=1.44 ; \quad C_{2 \varepsilon}=1.92 .
\end{gathered}
$$

The boundary conditions for the turbulence model are defined as follows (kinetic energy of turbulence at the inlet):

$$
k_{\text {in }}=1.5\left(u_{i, i n} T u\right)^{2}
$$

It should be noted that the modeling of flows in the presence of turbulence, which are taken as a basis for solving the equations for the turbulent characteristics (kinetic energy of turbulence and its dissipation), allows to obtain the desired accuracy of the solution, while excluding non-useful machine costs associated with obtaining it.

\section{Results of CFD research}

Simulation tool FLOREAN allows to get detailed information about furnace performance including velocities, temperature, thermal radiation and concentration distributions, etc. within the furnace and along the walls. The efficient combustion of solid fuel in combustion chambers and the efficient heat transfer to water and steam in steam generators are essential for the economical operation of power plants. This information is useful to evaluate the combustion process and to design optimal furnaces. FLOREAN will also be very useful in improving combustion process of different fuels in industrial boilers, optimizing operation and minimizing pollutant emission [9-11].

Consequently, the FLOREAN - code was used to predict thermal and hydrodynamic aspects of flue gases mixing in the near wall region and inside the furnace. In the case of Over Fire Air (OFA) technology of simulations show that effective mixing between flue gases and over-fire air is of essential importance for $\mathrm{CO}$ re-burning and low NOx emissions:

$$
2 \mathrm{CO}+\mathrm{O}_{2}=2 \mathrm{CO}_{2}+571 \mathrm{~kJ} / \mathrm{mol}
$$

The special importance during the combustion of pulverized coal gets the oxidation of carbon to carbon monoxide $\mathrm{CO}$, as further $\mathrm{CO}$, reacts with oxygen in the air, «burns down» to $\mathrm{CO}_{2}$, while allocating thus the maximum energy equal to 571 $\mathrm{kJ} / \mathrm{mol}$ [12]. Analysis of figures 4-5 shows that maximum values of carbon monoxide $\mathrm{CO}$ takes in the central section in location area of burners, because here there is observed the region of high temperatures $\left(\sim 1740 \quad{ }^{\circ} \mathrm{C}\right)$, there is a large concentration of fuel carbon and oxidant's oxygen.

The figure 4 represents the three-dimensional distribution of the concentration of carbon monoxide $\mathrm{CO}$ in the lower section of the burner $(\mathrm{Z}=10,8 \mathrm{M})$ and the figure 5 shows the same disrtibution in the longitudinal sections $(\mathrm{Y} 1=$ $2.95 \mathrm{~m}, \mathrm{Y} 3=11.47 \mathrm{~m}$ ) of the combustion chamber.

Comparative analysis of the graphs in Figure 4 shows that the mass flow of additional air, which is equal to $5 \mathrm{~kg} / \mathrm{s}$, the maximum value of the $\mathrm{CO}$ concentration reaches $1.72 \cdot 10^{-2} \mathrm{~kg} / \mathrm{kg}$, and at 10 $\mathrm{kg} / \mathrm{s}$ reaches the value of $9,3 \cdot 10^{-3} \mathrm{~kg} / \mathrm{kg}$. This is due to the fact that the value of air of $5 \mathrm{~kg} / \mathrm{s}$ temperature in the combustion chamber more than at $10 \mathrm{~kg} / \mathrm{s}$ and fuel oxidation process occurs actively. Analysis of Figure 4 shows that the concentration of carbon monoxide $\mathrm{CO}$ near the wall, which is opposite for the burners with holes is less for the case where the secondary air flow rate is $10 \mathrm{~kg} / \mathrm{s}$.

In the figure 5 there are represents the threedimensional distribution of the concentration of carbon monoxide $\mathrm{CO}$ in the lower section of the burner $(\mathrm{Z}=6.82 \mathrm{~m})$ and longitudinal sections $(\mathrm{Y} 1=$ $2.95 \mathrm{~m}, \mathrm{Y} 3=11.47 \mathrm{~m}$ ) of the combustion chamber. May be noted that the concentration of carbon monoxide $\mathrm{CO}$ in the whole cross-sections indicated as less than in the case where the additional air flow is $10 \mathrm{~kg} / \mathrm{s}$. Such a reduction in the concentration of $\mathrm{CO}$ can be explained by the greater concentration of oxidant $\left(\mathrm{O}_{2}\right)$ for this case, and a more complete combustion of the carbon to $\mathrm{CO}$ and its further conversion into $\mathrm{CO}_{2}$.

The figure 6 shows the distribution of the mean values of the concentrations of carbon monoxide $\mathrm{CO}$ by height of the combustion chamber for two different values of the additional air mass flow through the holes which are located on the walls opposite for the burners. 
We can see that as the three-dimensional color graphs on the carbon monoxide field at the outlet from the combustion chamber at a mass flow of air, equal to 5 $\mathrm{kg} / \mathrm{s}$, the concentration of carbon monoxide $\mathrm{CO}$ is higher compared with the case when the flow rate is 10 $\mathrm{kg} / \mathrm{s}$.

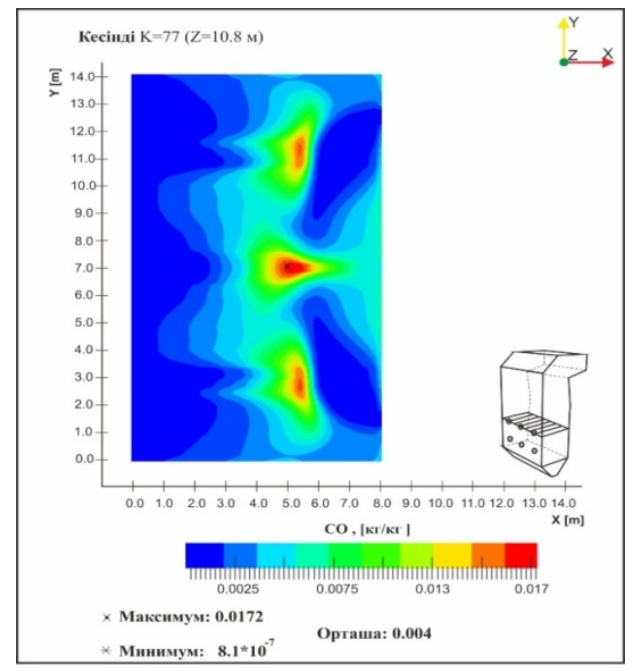

a) $5 \mathrm{~kg} / \mathrm{s}$

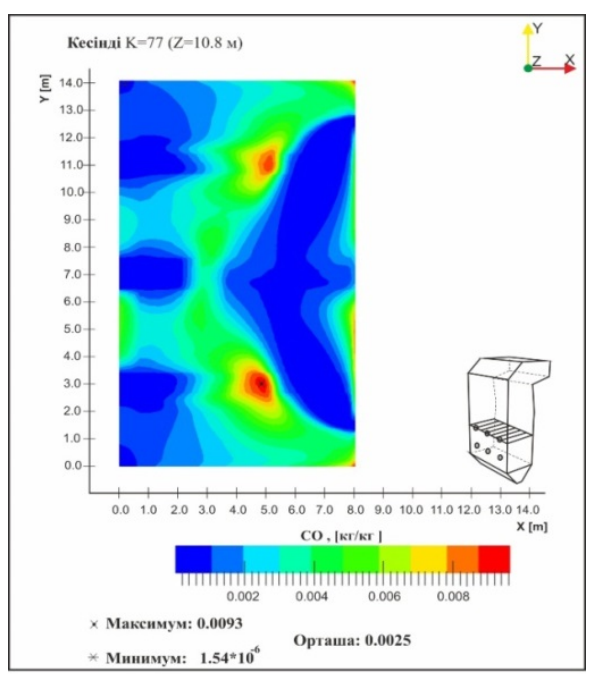

b) $10 \mathrm{~kg} / \mathrm{s}$

Figure 4 - The distribution of the carbon monoxide concentration $\mathrm{CO}$ in the cross section of the combustion chamber in the zone of upper burners $(\mathrm{h}=10.8 \mathrm{~m})$

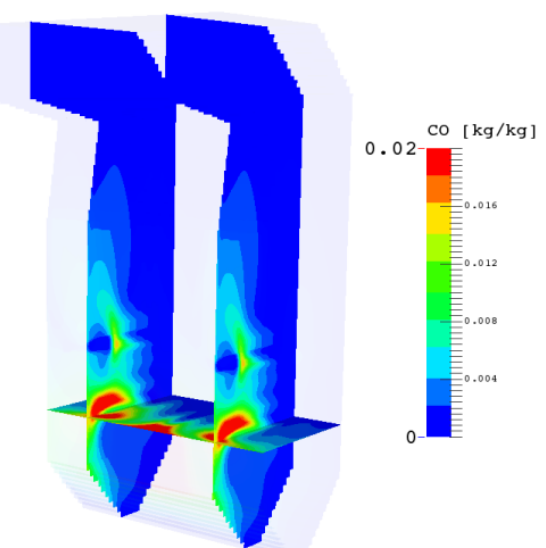

a) $5 \mathrm{~kg} / \mathrm{s}$

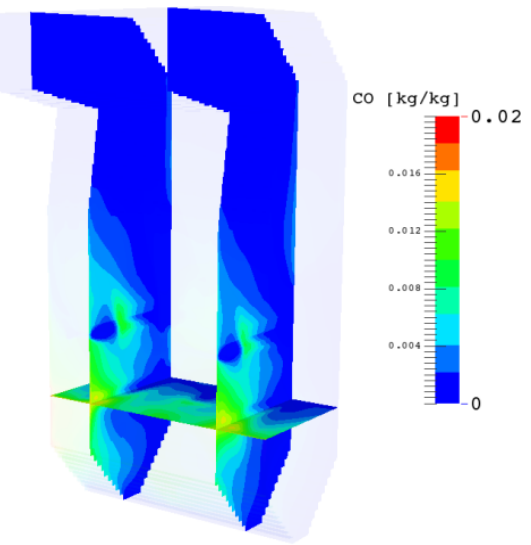

b) $10 \mathrm{~kg} / \mathrm{s}$

Figure 5 - The three-dimensional distribution of the concentration of carbon monoxide $\mathrm{CO}$ in the lower section of the burner $(\mathrm{Z}=6.82 \mathrm{~m})$ and longitudinal sections $(\mathrm{Y} 1=2.95 \mathrm{~m}, \mathrm{Y} 3=11.47 \mathrm{~m})$ of the combustion chamber 


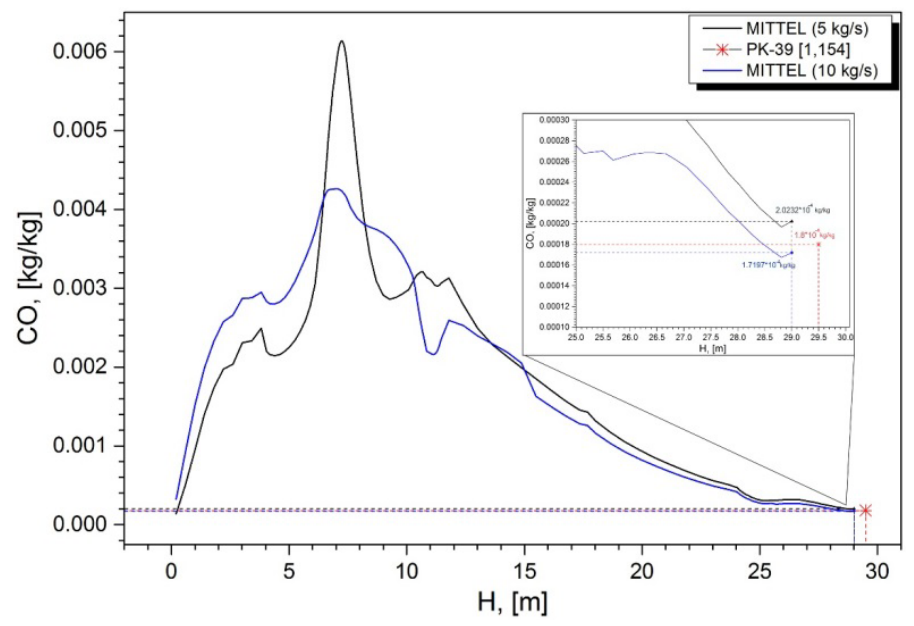

Figure 6 - The distribution of the concentration of carbon monoxide $\mathrm{CO}$ by height of the combustion chamber

Analysis of Figure 6 shows that the two curves reach a maximum in the location area of the burners. This is due to the largest concentration of entering in this part of the combustion chamber fuel ' $\mathrm{s}$ carbon and oxidant's oxygen, the intensity of physical and chemical interactions between them, which gives a high temperature here and heat generation due to chemical reactions between the components of the fuel and oxidant.

Analysis of figures 7-8 shows that the distribution of carbon dioxide $\mathrm{CO}_{2}$ is completely opposite to the character of the distribution of carbon monoxide $\mathrm{CO}$. One can see that in the upper zone of burners at a height of 10.8 meters the average concentration of carbon dioxide $\mathrm{CO}_{2}$ is

additional air through the holes in the wall of the combustion chamber, which are located opposite the burner devices is $10 \mathrm{~kg} / \mathrm{s}$, provides the optimal combustion mode.

Figure 9 provides a comparative graph of the distribution of average values of the carbon dioxide $\mathrm{CO}_{2}$ by height of the combustion chamber for two values of air mass flow rate of $5 \mathrm{~kg} / \mathrm{s}$ and $10 \mathrm{~kg} / \mathrm{s}$. By analyzing the graph it can be seen that in location area of the burners, and above them, the concentrations of carbon dioxide in the case when the flow rate of additional air through the holes in the wall of the combustion chamber which are located opposite the burners is $10 \mathrm{~kg} / \mathrm{s}$ higher than for the air flow rate $5 \mathrm{~kg} / \mathrm{s}$. This is confirmed by the three-dimensional fields of concentrations of $\mathrm{CO}_{2}$, presented in the Figures 7-8. Obviously this is due to the fact that in the case where the amount of secondary supplied air is greater, the combustion equal to $1.104 \mathrm{~kg} / \mathrm{kg}$ for the additional flow rate of air $-5 \mathrm{~kg} / \mathrm{s}$ and $0.11 \mathrm{~kg} / \mathrm{kg}$ is for flow rate $10 \mathrm{~kg} / \mathrm{s}$. In contrast to the distribution monoxide $\mathrm{CO}$, the average concentration of carbon dioxide $\mathrm{CO} 2$ as it moves out of the combustion chamber increases and the outlet takes a value equal to $0.172 \mathrm{~kg} / \mathrm{kg}$ for the flow rate of additional air $-5 \mathrm{~kg} / \mathrm{s}$ (Fig. 8a) and $0.164 \mathrm{~kg} / \mathrm{kg}$ to flow rate $10 \mathrm{~kg} / \mathrm{s}$ (Fig. $8 \mathrm{~b}$ ).

When flow rate of the additional air is equal to $10 \mathrm{~kg} / \mathrm{s}$ at the outlet of the combustion chamber the concentration of carbon dioxide $\mathrm{CO}_{2} 4.65 \%$ is less than a flow rate of air $5 \mathrm{~kg} / \mathrm{s}$, which corresponds to a maximum permissible standards accepted in current TPP. Therefore, we can conclude that the second case of combustion of fuel when the flow rate of reaction with formation of $\mathrm{CO}_{2}$ is occurred more intensively.

At the outlet of the $\mathrm{CO}_{2}$ concentration of the combustion chamber at high flow rate of air is less because the formation of carbon dioxide is dependent on the temperature values. In the case where the additional air flow rate is $10 \mathrm{~kg} / \mathrm{s}$, the temperature at the outlet of the combustion chamber is lowered by $58 \circ \mathrm{C}$, create conditions for incomplete reaction afterburning $\mathrm{CO}$ to $\mathrm{CO}_{2}$, which resulted in a decrease in the concentration of carbon dioxide at the outlet of the combustion chamber. Although this reduction is small and is 4.65\% [13]. So we have to a greater flow of additional air $\mathrm{CO} 2$ concentration on the yield equal to $0.164 \mathrm{~kg} / \mathrm{kg}$ to less rate $-0.172 \mathrm{~kg} / \mathrm{kg}$.

In the area of the burners (Fig. 10) the maximum concentration of $\mathrm{NO}_{2}$ for additional air mass flow of $5 \mathrm{~kg} / \mathrm{s}$ is $7812.4 \mathrm{mg} / \mathrm{Nm}^{3}$, while for the $10 \mathrm{~kg} / \mathrm{s}-$ 
$3256.6 \mathrm{mg} / \mathrm{Nm}^{3}$. As one moves out of the combustion chamber (Fig. 11) there is a decrease the concentration of $\mathrm{NO}_{2}$. The maximum concentration at the outlet of the combustion chamber for the base case is $879.8 \mathrm{mg} / \mathrm{Nm}^{3}$, as proposed by us for the case is $680 \mathrm{mg} / \mathrm{Nm}^{3}$.

At the outlet (Fig. 11) we have a mean concentration $\mathrm{NO}_{2}=761 \mathrm{mg} / \mathrm{Nm}^{3}$ for additional air rate equal to $5 \mathrm{~kg} / \mathrm{s}$ (Fig. 11a), and the average concentrations of $\mathrm{NO}_{2}$ in the cross section at the outlet equal to $655 \mathrm{mg} / \mathrm{Nm}^{3}$ to the flow rate $-10 \mathrm{~kg}$ /s (Fig. 11b), which is quite acceptable emission standards for NO2, adopted by the TPP. In the proposed variant of the coal combustion (additional air flow rate is $10 \mathrm{~kg} / \mathrm{s}$ ) decreased by $14 \%$ in comparison with the first case. So it can be seen that increasing submitted air rate further reduces the average concentration of nitrogen dioxide $\mathrm{NO}_{2}$.

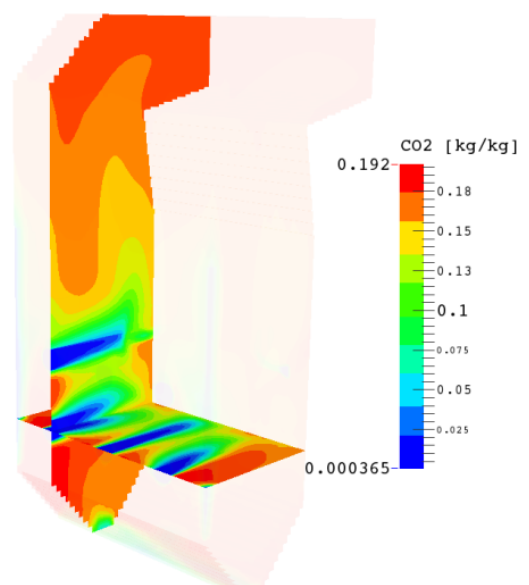

a) $5 \mathrm{~kg} / \mathrm{s}$

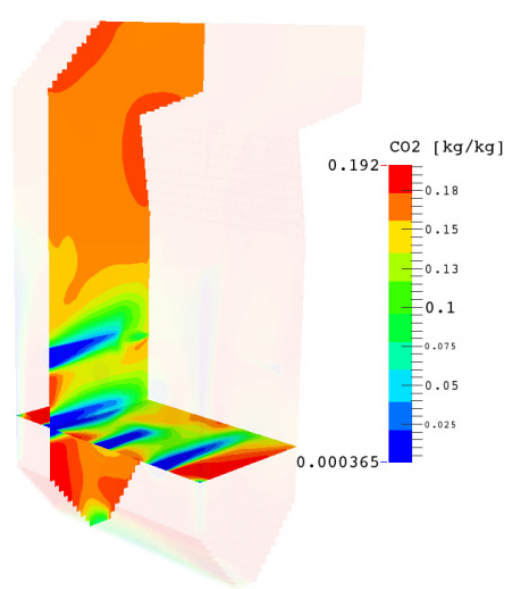

b) $10 \mathrm{~kg} / \mathrm{s}$

Figure 7 - The three-dimensional distribution of carbon dioxide $\mathrm{CO}_{2}$ in the lower section of the burners $(\mathrm{Z}=6.82 \mathrm{~m})$ and in the longitudinal section $(\mathrm{Y} 1=2.95 \mathrm{~m})$ of the combustion chamber

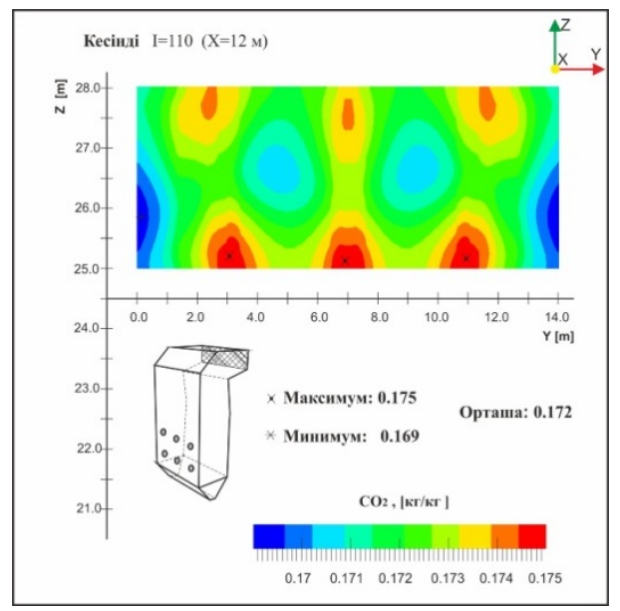

a) $5 \mathrm{~kg} / \mathrm{s}$

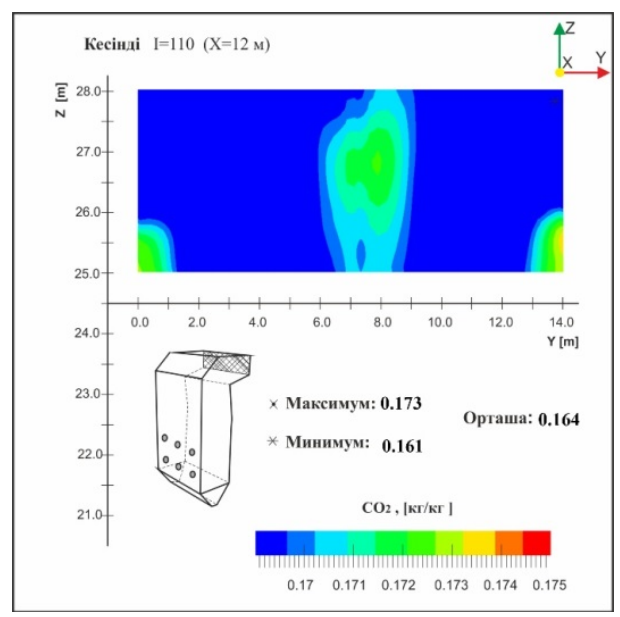

b) $10 \mathrm{~kg} / \mathrm{s}$

Figure 8 - The distribution of the carbon dioxide $\mathrm{CO}_{2}$ concentration at the outlet of the combustion chamber $(\mathrm{X}=12 \mathrm{~m})$ 


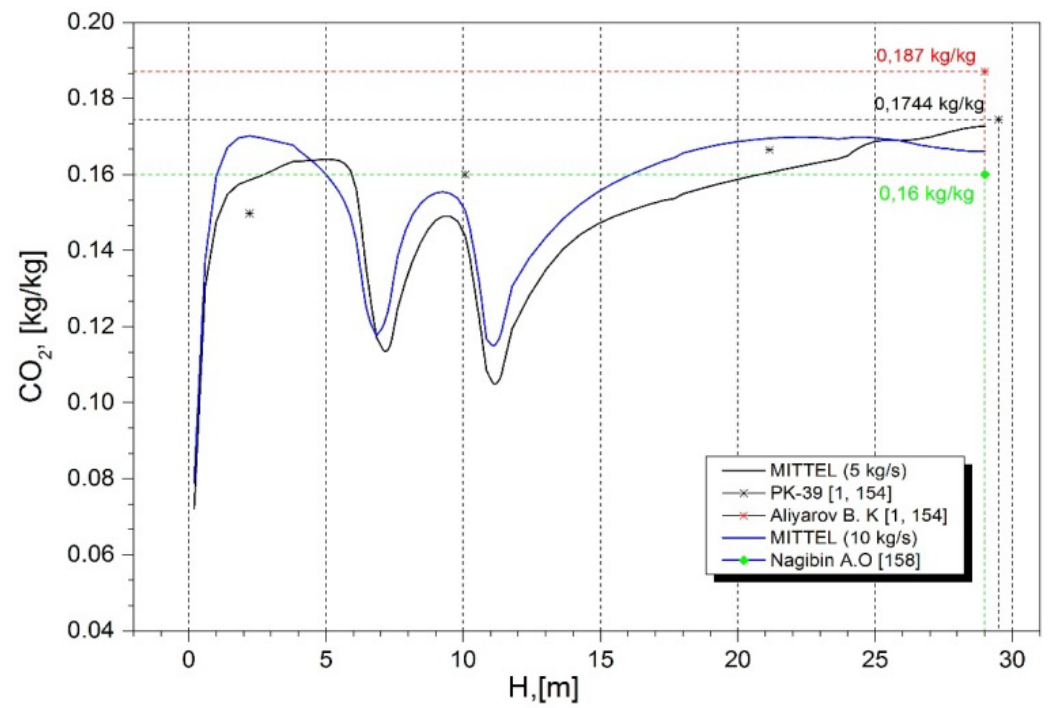

Figure 9-Graph of distribution of average values of carbon dioxide $\mathrm{CO}_{2}$ by height of the combustion chamber for different values of mass flow rate of additional air

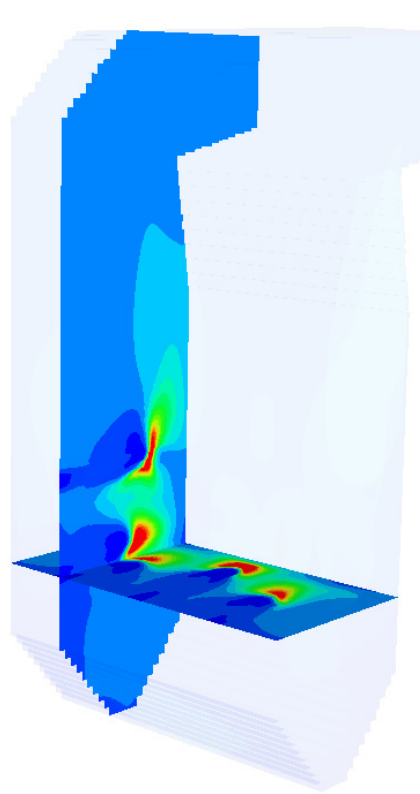

a) $5 \mathrm{~kg} / \mathrm{s}$

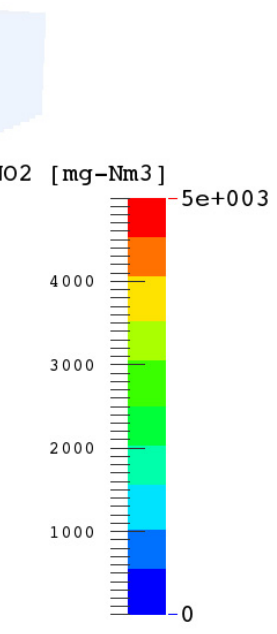

b) $10 \mathrm{~kg} / \mathrm{s}$

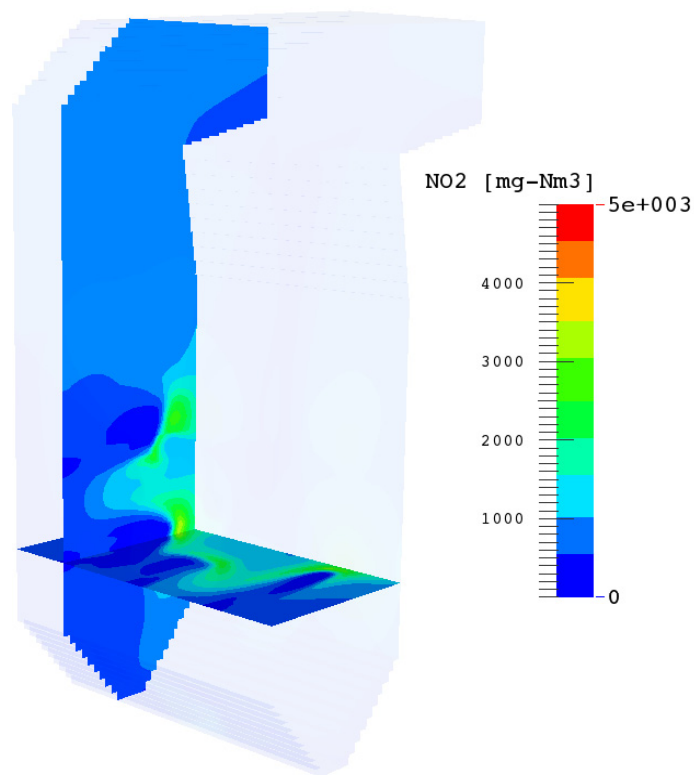

Figure 10 - The three-dimensional distribution of the nitrogen dioxide $\mathrm{NO}_{2}$ in the lower area of the burner $(\mathrm{Z}=6.82 \mathrm{~m})$ and in longitudinal section $(\mathrm{Y} 1=2.95 \mathrm{~m})$ of the combustion chamber 


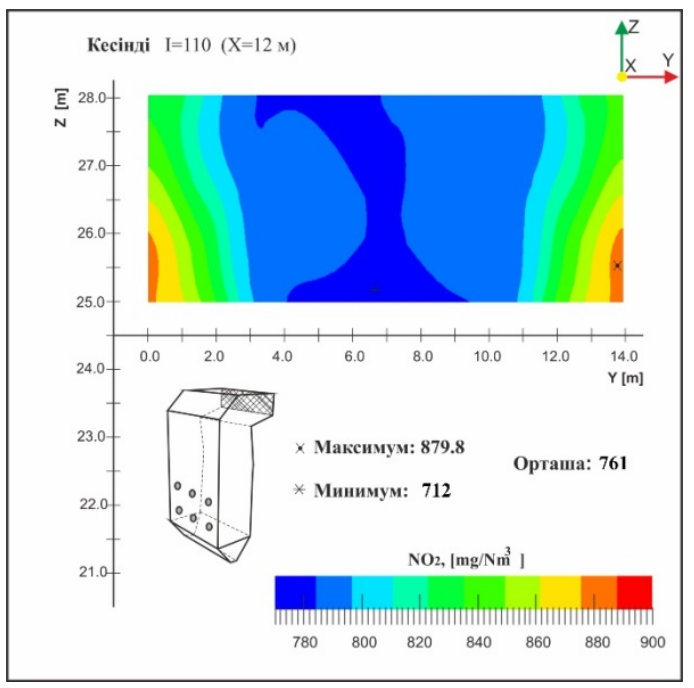

a) $5 \mathrm{~kg} / \mathrm{s}$

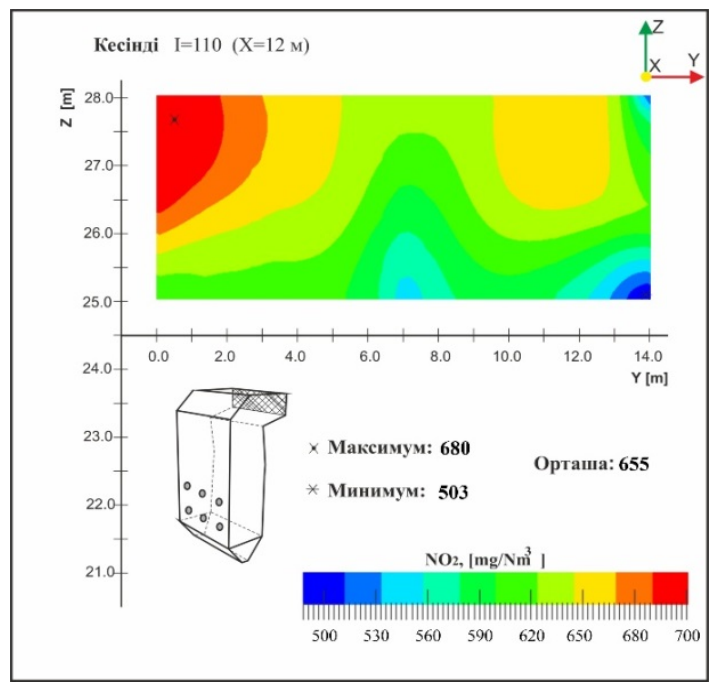

b) $10 \mathrm{~kg} / \mathrm{s}$

Figure 11 - The concentration distribution of nitrogen dioxide $\mathrm{NO}_{2}$ at the outlet of of the combustion chamber $(\mathrm{X}=12 \mathrm{~m})$

\section{Conclusion}

This article has been developed optimal combustion technology of high-energy fuel and the best design parameters of the combustion chamber of the boiler BKZ-420 of the Almaty TPP-2 that improve the durability of the power equipment and reduce the emissions of harmful substances into the atmosphere. The proposed Ekibastuz coal combustion technology reduces the temperature of the furnace wall, opposite the burners on the 3000 ${ }^{0} \mathrm{C}$, that is to $17.24 \%$, and also reduces the average carbon monoxide concentration $\mathrm{CO}$ at the outlet of the furnace up to $15 \%$, carbon dioxide $\mathrm{CO}_{2}-$ $4.65 \%$, and nitrogen dioxide $\mathrm{NO} 2-14 \%$.

The concentration of carbon monoxide can be reduced due to an increase in the excess air ratio in the combustion chamber and the high temperatures in it. However, increase in temperature in the combustion chamber invariably leads to increased formation of nitrogen oxides $\mathrm{NOx}\left(\mathrm{NO}\right.$ and $\left.\mathrm{NO}_{2}\right)$, which are recognized at the present time, the most toxic environmental pollutants. $90 \%$ of the total amount of nitrogen oxides is nitrogen monoxide $\mathrm{NO}$, which is further oxidized to NO2. The NOx cause acidification of atmospheric precipitation contribute to photochemical air pollution and the thinning of the ozone layer. Reducing the concentration of nitrogen oxides NOx, generated by combustion of coal is one of the main tasks in the development and operation of power devices [14$16]$.

During the flow rate of the additional air equal $10 \mathrm{~kg} / \mathrm{s}$ at the outlet of the combustion chamber the concentration of carbon dioxide $\mathrm{CO}_{2} 4.65 \%$ is less than a flow rate of air $5 \mathrm{~kg} / \mathrm{s}$, which corresponds to a maximum permissible standards adopted for TPP. So, we can conclude that the second case of combustion of fuel when the flow rate of additional air through the holes in the wall of the combustion chamber which located opposite the burner units is $10 \mathrm{~kg} / \mathrm{s}$, provide optimal combustion mode.

The results have scientific value and provide more insight into the mechanism of turbulent combustion of pulverized coal in the combustion chambers of power plants, which in turn contributes to the solution of fundamental problems of modern thermal physics, Macrokinetics, the theory of combustion explosion.

\section{References}

1. Messerle V.E., Lavrishcheva Ye.I., Karpenko E.I., et al. Plasma-supported coal combustion in boiler furnace // IEEE Transactions on Plasma Science. - 2007. - Vol. 35, No 6. P.1607-1616.

2. Ustimenko A.B., Askarova A.S., Messerle V.E., Nagibin A. Pulverized coal torch combustion in a furnace with plasma-coal system // 
Journal of Thermophysics and Aeromechanics. 2010. - Vol.7, No 3. - P. 435-444.

3. Karpenko E.I., Messerle V.E. et al. Plasma enhancement of combustion of solid fuels // Journal of High Energy Chemistry. - 2006. - Vol. 40, No 2. - P.111-118.

4. D Askarova A.S., Lavrichsheva Ye., Leithner R., Müller H., Magda A. Combustion of low-rank coals in furnaces of Kazakhstan Coal-firing Power Plants // VDI Berichte. - 2007. -No 1088. - P. 497-502.

5. Vockrodt S., Leithner R., Schiller R., Buchman M. Firing technique measures for increased efficiency and minimization of toxic emissions in Kasakh coal firing // VDI BERICHTE. - Dresden. - 1999. - Vol. 1492. - P. 93-97.

6. B Abbas T., Costen P.G. and Lockwood F.C. Solid Fuel Utilisation: From Coal to Biomass Twenty-Sixth Symposium (International) on Combustion, The Combustion Institute, Pittsburgh. $-1996 .-3041 \mathrm{p}$.

7. Bolegenova S.A., Messerle V.E., Maksimov V.Yu. et al. Numerical Simulation of the Coal Combustion Process Initiated by a Plasma Source // Journal of Thermophysics and Aeromechanics. 2014. - Vol. 21, No 6. - P.747-754.

8. Leithner, R., Müller, H. CFD studies for boilers Second M.I.T. Conference on Computational Fluid and Solid Mechanics - Cambridge. - 2003. $172 \mathrm{p}$.

9. Karpenko Yu.E., Karpenko E.I., Askarova A.S. et al. Mathematical modeling of the processes of solid fuel ignition and combustion at combustors of the power boilers // 7-th International Fall Seminar on Propellants, Explosives and
Pyrotechnics. Theory and Practice of Energetic Materials. - China. - 2007. - Vol. 7. - P. 672-683.

10. L Buchmann M.A., Askarowa A. Structure of the flame of fluidized-bed burners and combustion processes of high-ash coal // VDI BERICHTE. - 1997. - Vol. 1313. - P. 241-244.

11. Bekmukhamet A., Beketayeva M.T., Sh.S., Gabitova Z.K. et al. Numerical modeling of turbulence characteristics of burning process of the solid fuel in BKZ-420-140-7c combustion chamber // International Journal of Mechanics. - 2014. Vol.8. - P.112-122.

12. Askarova A.S., Maksimov V.Yu., et al. Computational method for investigation of solid fuel combustion in combustion chambers of a heat power plant // Journal of High Temperature. - 2015. - Vol.53,No 5. - P. 751-757.

13. Bolegenova S.A., Bekmuhamet A., et al. Using $3 \mathrm{~d}$ modeling technology for investigation of conventional combustion mode of bkz-420-140-7c combustion chamber // Journal of Engineering and Applied Sciences. - 2014. - Vol. 9. - P.24-28.

14. Messerle V.E., Maksimov V.Yu., et al. Numerical simulation of pulverized coal combustion in a power boiler furnace // Journal of High Temperature. - 2015. - Vol.53, No 3. - P.445-452.

15. Safarik P., Askarova A.S., et al. Numerical Modeling of Pulverized Coal Combustion at Thermal Power Plant Boilers // Journal of Thermal Science. - 2015. - Vol. 24,No 3. - P.275-282.

16. Loktionova I.V., Messerle V.E., et al. 3D modeling of the two-stage combustion of Ekibastuz coal in the furnace chamber of a PK-39 boiler at the Ermakovo district power station // Journal of Thermal engineering. - 2003. - Vol. 50, No 8. - P.633-638. 